\title{
A Preliminary Study: Identification of Stream Waste Quantity and Composition in Bali Province, Indonesia
}

\author{
I Made Wahyu Widyarsana ${ }^{1}$,Enri Damanhuri ${ }^{2}$, Nida $_{\text {Ulhusna }}{ }^{3}$, and Elprida Agustina ${ }^{4}$ \\ 1,2,3,4 Faculty of Civil and Environmental Engineering, Bandung Institute of Technology, Indonesia
}

\begin{abstract}
Bali Province is an island of high tourist activity surrounded by the sea. Without a proper mainland waste management, waste problem will impact the aquatic environment. River and beach are waterways that become an important role in the waste flow that will end to the sea. Identification of waste in rivers and beaches is needed to determine the stream waste management policy. Measurements were made by adopting the NOAA (National Oceanic and Atmospheric Administration) method on 4 rivers and 4 beaches. Measurement of waste generation and composition represents the watershed and population density classification groups. The peak hour for the waste streams at 11.00-14.00 WITA $(\mathrm{GMT}+8)$. The dominant waste is organic waste $(59.10 \% \mathrm{WW})$ and hazardous waste $(17.12 \% \mathrm{WW})$. From the waste measurement on the beach, the waste density is around 0.087 tonnes $/ \mathrm{m}^{3}$ and the composition of waste is dominated by plastic waste, paper waste, and textile waste. The average waste density in beach is around $0.007 \mathrm{~kg} / \mathrm{m}^{2}$ or 0.53 items $/ \mathrm{m}^{2}$. Yeh Gangga Beach is the dirtiest with 0.64 items waste $/ \mathrm{m}^{2}$ and Lepang Beach is the cleanest beach with 0.27 items $/ \mathrm{m}^{2}$.
\end{abstract}

\section{Introduction}

Illegal waste disposal still occurring in Indonesia, both on vacant land and in waters, which will produces pollution and negative impacts on the environment. Waste disposal to waterways will eventually lead to the sea, which can also damage the ecosystem and marine life. The beach as a medium of transition between land and sea is one indicator to determine cleanliness and environmental pollution, especially those that affect the sea. The beach is also one of the recreational facilities that can have a distinctive influence on sea pollution due to the waste generation by tourists. In general, decreases water quality in river and sea have occurred since a few years ago due to natural and human factors, which then make ecosystems vulnerable to pests and waste [1]. Oceanic waste can also be transported by ocean currents and wind from one place to another, and can even travel great distances from its source [2].

Bali Province, as one of the most desirable tourist destinations in Indonesia, surrounded by the sea, certainly has a big impact on the health of the sea and the aquatic environment followed by the presence of local and foreign tourists who continue to increase every year will affect the amount of waste generation generated.

River and coastal management can sometimes be a difficult challenge because of the need to take into account cross-border physical and political interactions [3]. Previous studies have found that $40-80 \%$ of large marine waste ( $>20 \mathrm{~mm}$ diameter) is plastic, and is generally associated with food and beverage products including bottles, bottle caps, bags, drinking straws, and polystyrene pieces [4]. And several other studies also found the accumulation of plastic on land and fresh water as a pathway of waste into the environment [5]. Other studies also note that the total amount of marine debris floating around the world ranges from $0-10$ pieces per $\mathrm{km}^{2}$, whereas in Indonesia the number can reach 4 pieces per $\mathrm{m}^{2}$, and the maximum amount of waste that reaches coastal waters is found in Indonesia where the number reached 29.1 pieces per meter [6].

A great effort is needed to clean up marine debris [7]. In addition, to clean up marine debris that reaches the beach also requires a considerable cost, it was noted that the provincial government of Bali has spent approximately IDR 500,000,000 for the cost of cleaning the beach from ocean waste [8]. There are also non-governmental organizations such as the Quicksilver Foundation, CocaCola, and Ripcurl which issue billions of rupiah each year to clean up trash and provide education on environmental protection [8].

Efforts that have been made include making international policies to prevent the disposal of trash into the oceans from ships (International Convention for the Prevention of Pollution from Ship - MARPOL), conducting studies on the movement of litter and efforts to clean up waste that reaches the ocean [6]. However, these efforts still have not provided practical solutions, especially in non-European regions [9]. Other recent efforts that have been made include the government 
regulation regarding the handling of marine waste which is regulated in Presidential Regulation No. 83 of 2018 and Presidential Regulation No. 97 of 2017 concerning National Policies and Strategies for the Management of Household Waste and Similar Household Waste, is targeted for 2025 to occur in the handling of waste by $70 \%$.

So this research is therefore conducted to find out the amount of solid waste generation and composition of waste in rivers and beaches as one of the considerations in implementing waste management development policy in Bali Province, especially for the stream waste.

\section{Background of Study Area}

Geographically the Bali Province is located at $8^{\circ} 3^{\prime} 40$ "$8^{\circ} 50^{\prime} 48^{\prime \prime}$ South Latitude and $114^{\circ} 25^{\prime} 53^{\prime \prime}-115^{\circ} 42^{\prime} 40^{\prime \prime}$ East Longitude. Relief and topography of the island of Bali in the midst of a mountain range that extends from west to east. The Province of Bali is located between Java and Lombok. The physical boundaries are as follows:

$$
\begin{aligned}
& \text {-North } \quad \text { : Bali Sea } \\
& \text {-East } \quad \text { : Lombok Strait (West Nusa Tenggara } \\
& \text { Province) } \\
& \text {-South } \quad \text { : Indonesian Ocean } \\
& \text {-West } \quad \text { : Bali Strait (East Java Province) }
\end{aligned}
$$

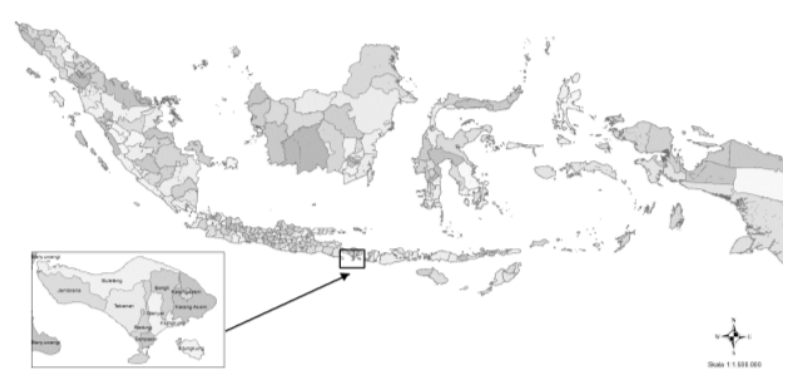

Fig. 1. Location of Bali

Bali Province consists of 9 (nine) cities / regencies consisting of Denpasar City as the Capital of the Province, Badung Regency, Karangasem Regency, Jembrana Regency, Bangli Regency, Buleleng Regency, Klungkung Regency, Tabanan Regency, and Gianyar Regency. The total area of Bali Province reaches $5,636.66 \mathrm{~km}^{2}$ or $0.26 \%$ of the total area of the Indonesian archipelago [10]. Of the 9 (nine) cities / regencies, Buleleng Regency has the largest area of $1,365.88 \mathrm{~km}^{2}(24.23 \%)$ of the total area of the province, followed by Jembrana $841.80 \mathrm{~km}^{2} \quad(14.93 \%)$, Karangasem $839.54 \mathrm{~km}^{2}$ (14.89\%), and Tabanan 839.33 $\mathrm{km}^{2}(14.89 \%)$. The rest are respectively Bangli 520.81 $\mathrm{km}^{2}$, Badung $418.52 \mathrm{~km}^{2}$, Gianyar $368.00 \mathrm{~km}^{2}$, Klungkung $315.00 \mathrm{~km}^{2}$, and Denpasar City $127.78 \mathrm{~km}^{2}$.

It is known that total river length in North Bali reached $989.96 \mathrm{~km}(18.95 \%)$, in West Bali as many as 1,497.92 $\mathrm{km}(28.67 \%)$. Whereas in East Bali it could reach $1,051.15 \mathrm{~km}(20.12 \%)$, and in South Bali there were
$1,684.89 \mathrm{~km}(32.25 \%)$. Meanwhile total coastal length in 9 (nine) regencies / cities reached 633,352 km as listed in Table 1.

Table 1 Coastline Length in Bali Province

\begin{tabular}{|c|l|l|}
\hline No & \multicolumn{1}{|c|}{ Regency/City } & \multicolumn{1}{|c|}{ Coastline Length $(\mathrm{km})$} \\
\hline 1 & Buleleng & 172,301 \\
\hline 2 & Karangasem & 86,070 \\
\hline 3 & Klungkung & 113,397 \\
\hline 4 & Gianyar & 14,284 \\
\hline 5 & Denpasar & 46,164 \\
\hline 6 & Badung & 83,786 \\
\hline 7 & Tabanan & 30,177 \\
\hline 8 & Jembrana & 87,173 \\
\hline \multicolumn{2}{|c|}{ TOTAL } & 633,352 \\
\hline
\end{tabular}

\section{Methods}

Various activities are carried out to collect data in this study such as primary data collection and secondary data. The primary data collection is done by sampling waste generation directly, while secondary data collection is done to the relevant institutions to determine the waste management system as well as the handling of plastic waste in 9 (nine) city / regencies in Bali.

\subsection{Observations}

Observation of waste conditions in 9 (nine) cities / regencies is carried out, especially in the area that will be used as a sampling location. Observations included the general environmental conditions of community settlements, in community settlements near rivers, in waste treatment facilities, transfer depots, and final processing sites.

\subsection{Interview}

The amount of waste dispose into the environment, especially rivers, and handling of waste at the source, is obtained from the structured interviews using questionnaires and observations of the community around the riverbanks, which are supported by secondary data in the form of existing conditions of waste services. In the sampling plan, it is assumed that the waste dumped into the river comes from the people who live at 500 meters from the river banks, from left and right side of the river.

So with an average population density of Bali Province of 735 people $/ \mathrm{km}^{2}$, total river length of $5,223.92 \mathrm{~km}$, and a population of 4,246,500 people in 2017 obtained from the Central Bureau of Statistics of the Province of Bali, the magnitude of the population near the river $(\mathrm{P})$ of the equation can be obtained following.

$$
P=L \times A \times K
$$


It was obtained that the community near the river in North Bali reached 745,520 people $(18.95 \%)$, in West Bali as many as $1,128,026$ people $(28.67 \%)$. Whereas in East Bali it could reach 791,588 people $(20.12 \%)$, and in South Bali there were 1,268,792 people $(32.25 \%)$. Then the value of $\mathrm{P}$ as much as $3,933,926$ people.

Then the sample size of interviews and observations will be carried out using the Yamane equation (1967: 886) as follows.

$$
n=N /\left(1+N(e)^{2}\right)
$$

With $\mathrm{n}$ being the number of samples, $\mathrm{N}$ is the total population which in this case is the total population living near the river, and e is the level of precision which in this study used a $95 \%$ confidence level. Then obtained the number of samples needed as follows.

$n=3,933,925 /\left(1+3,933,926(0.05)^{2}\right)=399.96$

$n=400$ inhabitats

With an average population of 1 (one) family of 5 people, the household sample needed is 80 households or 80 samples to be divided by percentage of population in each part of the region.

Table 2 Number of Respondents

\begin{tabular}{|l|l|l|}
\hline Region & $\begin{array}{c}|c| \\
\text { Percentage of } \\
\text { Population } \\
(\%)\end{array}$ & $\begin{array}{c}\text { Sample } \\
\text { (Family) }\end{array}$ \\
\hline West & $28.67 \%$ & 23 \\
\hline South & $32.24 \%$ & 25 \\
\hline East & $20.12 \%$ & 16 \\
\hline North & $18.96 \%$ & 16 \\
\hline TOTAL & $100 \%$ & 80 \\
\hline
\end{tabular}

\subsection{Measurement of Waste Generation and Composition}

The number of samples used is based on 4 (four) large groups of regional divisions in the Bali Province, which were obtained based on the Watershed Area (DAS) in the Bali Province. The group includes North Bali, East Bali, West Bali and South Bali.

North Bali consists of Buleleng Regency, Bangli Regency, and a small area in Karangasem Regency which is marked in purple with ID DAS 050 to 140 . West Bali is represented by Jembrana Regency, a small portion of Tabanan Regency and part of Buleleng Regency with id DAS 001 - 049, 303 - 327, and 328 331 which are marked in pink. Whereas East Bali consists of Karangasem Regency, Klungkung Regency, and parts of Bangli Regency with DAS 141 - 215 which are marked in yellow. And South Bali is represented by Tabanan Regency, Badung Regency, Denpasar City, Gianyar Regency, and parts of Bangli Regency with ID DAS 216 - 302 marked in blue. Whereas Klungkung Kepulauan Regency is not included in this study as stated in Figure 2.

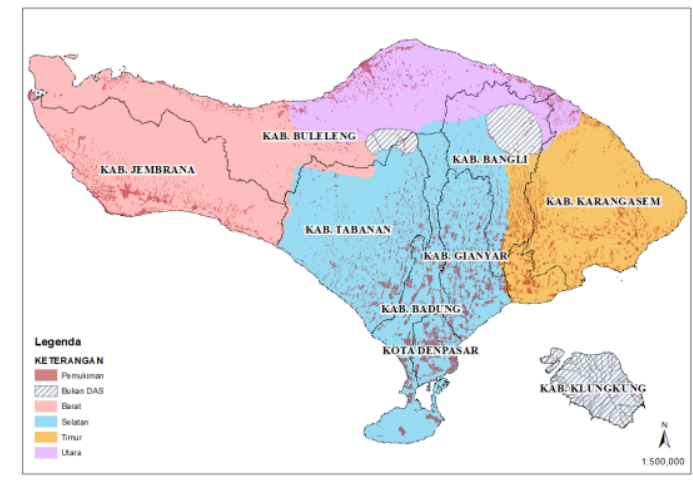

Fig. 2. Distribution of watershed in Bali Province

To determine the sampling location, besides looking at the location of the river, it is necessary to consider the existence or location of settlements around the river.

So that when viewed from the distribution of population density in Bali Province, it was found that there are 5 (five) classifications of population density illustrated by Figure 3.

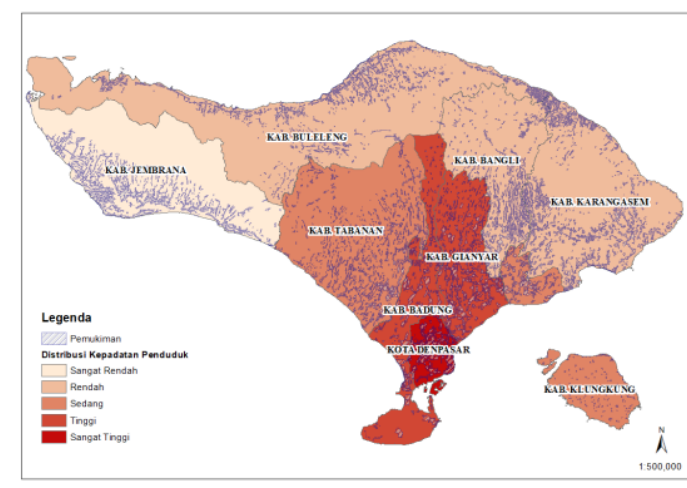

Fig. 3. Classification of Population Density

The group division of population density in Bali Province as listed in Table 3.

Table 3 Classification of Population Density

\begin{tabular}{|c|c|l|}
\hline Classification & $\begin{array}{c}\text { Density } \\
\left(\text { People } / \mathrm{km}^{2}\right)\end{array}$ & \multicolumn{1}{|c|}{ Regency } \\
\hline Very Low & $<340$ & Jembrana \\
\hline Low & $341-500$ & $\begin{array}{l}\text {-Buleleng } \\
\text {-Karangasem } \\
\text {-Bangli }\end{array}$ \\
\hline Medium & $510-1,000$ & $\begin{array}{l}\text {-Klungkung } \\
\text {-Tabanan }\end{array}$ \\
\hline High & $1,001-5,000$ & $\begin{array}{l}\text {-Badung } \\
\text {-Gianyar }\end{array}$ \\
\hline Very High & $>5,001$ & Denpasar \\
\hline
\end{tabular}

So that it is determined for the South Bali region and high population density will be represented by the Loloan River in Denpasar City, which is also a river representative with a trashrack which estuary on Mertasari Beach. The East Bali region will be represented by the Jangga River in Karangasem Regency and estuary on Jasri Beach. While moderate population density will be represented by the Yeh Empas River in Tabanan Regency which estuary on Yeh Gangga Beach 
and Jinah River located in Klungkung Regency which estuary on Lepang Beach.

The four sampling locations were chosen to represent the watershed conditions and population density of Bali Province which are dominated by southern watersheds and low population densities.

The amount of waste entering the river is obtained from the amount of waste retained in a net installed for 24 hours in 3 days in a river close to the settlement, with collection every hour starting at $09.00-16.00$ WITA and for the waste generation at night it is taken the next morning. Meanwhile, the amount of waste in beach are taken everyday in 3 days on $20 \times 40$ meters samples area that change everyday, start from 50 meters from access center of the beach.

The average of waste obtained from 3 days of sampling that represent of possibility weekend and weekday activity on beaches and rivers, that can influence the amount of waste generation.

\section{Results}

Based on the methodology, primary data collection and composition of waste is carried out at 4 (four) river sampling locations and 4 (four) coastal sampling locations.

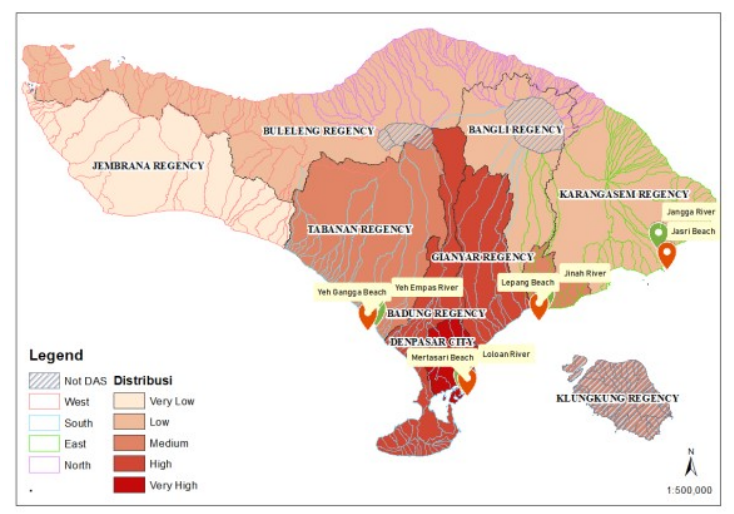

Fig. 4. Sampling Location

Then structured observations and interviews were carried out through a randomized questionnaire with a total of 92 respondents.

\subsection{Yeh Empas River (Tabanan Regency)}

The chosen river location is the Yeh Empas River which has a length of $98.51 \mathrm{~km}$ in width at sampling point of 8 meters. The Yeh Empas River located at $8^{\circ} 35^{\prime} 0.456^{\prime \prime}$ South Latitude, $115^{\circ} 5^{\prime} 5.568^{\prime \prime}$ East Longitude. The Yeh Empas River is in Bengkel Village, Tabanan District and is $2.6 \mathrm{~km}$ from the estuary located on Yeh Gangga Beach. Land around the river is still empty land, but there are already settlements with a distance of \pm 100 meters from the river. On the banks of the river, especially those under the bridge, there is a pile of waste thrown by the surrounding community.

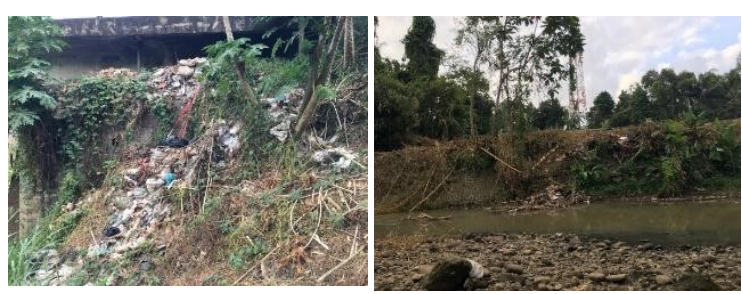

Fig. 5. Conditions of the Yeh Empas River

The location of the selected river is the Yeh Empas River where 3 out of 5 respondents $(60 \%)$ are 100,200 , and 300 meters from the river throw waste into empty land, and 2 others $(40 \%)$ within 300 and 400 meters throw waste in the yard of each house. And the average amount of waste retained in the net is $0.49 \mathrm{~kg} /$ hour with a density of 0.0115 tons $/ \mathrm{m}^{3}$. Fluctuations in river waste generation are shown in Figure 6 where the largest waste generation is obtained at $14.00-15.00$ WITA, reaching $2.55 \mathrm{~kg} /$ hour and the lowest waste generation reaching $0.14 \mathrm{~kg} /$ hour.

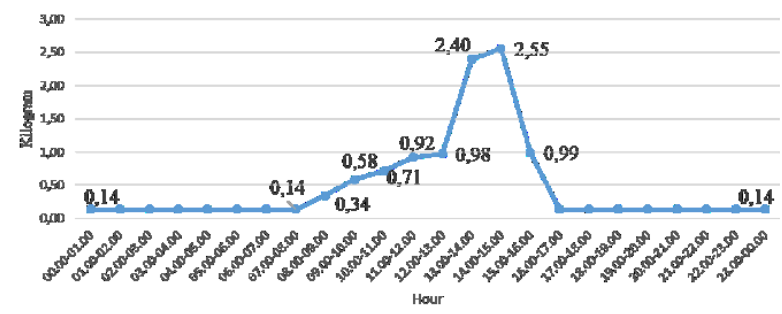

Figure 6. Fluctuation of the Yeh Empas River

It was found that the generation of waste in the river was dominated by organic waste in the form of leaves and twigs of $5.60 \mathrm{~kg} /$ day $(53.81 \% \mathrm{WW})$ followed by hazardous waste which included baby diapers or pads as much as $4.05 \mathrm{~kg} /$ day, equivalent to $38.93 \% \mathrm{WW}$. The other dominant is plastic waste of $0.44 \mathrm{~kg} /$ day $(4.25 \%$ WW), which includes LDPE and packaging.

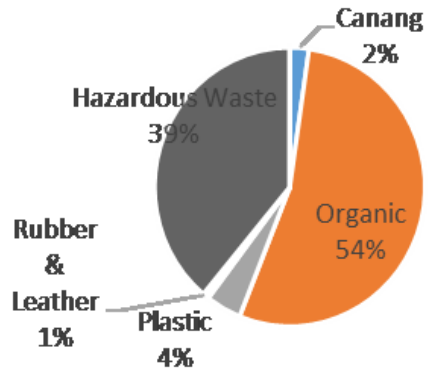

Fig. 7. Waste Composition of Yeh Empas River

\subsection{Jangga River (Karangasem Regency)}

The Jangga River used as a sampling location is located at $08^{\circ} 26^{\prime} 41.0568$ "N - 115³6'17.1144" E. The river point used is $6.1 \mathrm{~km}$ from the estuary located on Jasri Beach. The Jangga River itself has $9.9 \mathrm{~km}$ long and has a width of 7.1 meters at the sampling location. Land around the river functioned as settlements and rice fields. Current that flows an average of $0.517 \mathrm{~m} / \mathrm{s}$ with a water height of $40 \mathrm{~cm}$. On the banks of the Jangga River, there is residual waste burning by the local community. 


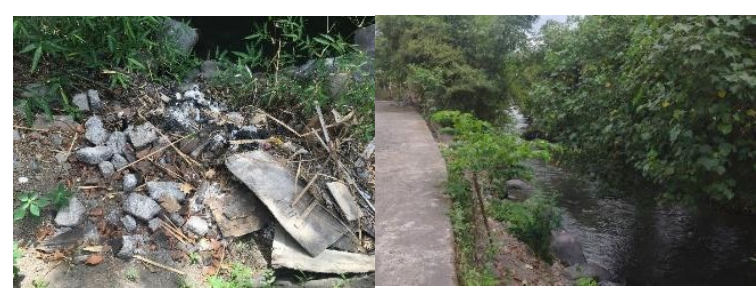

Fig. 8. Condition of the Jangga River

Obtained the average amount of waste retained in the net is $0.47 \mathrm{~kg}$ / hour or equivalent to $0.066 \mathrm{~kg} / \mathrm{m} /$ hour if divided by the width of the river with the fluctuation of waste listed in Figure 9. The largest waste generation is obtained at $12.00-13.00$ WITA which is $2.04 \mathrm{~kg}$ and the lowest waste generation is $0.16 \mathrm{~kg}$ with a density of 0.0115 tons $/ \mathrm{m}^{3}$.

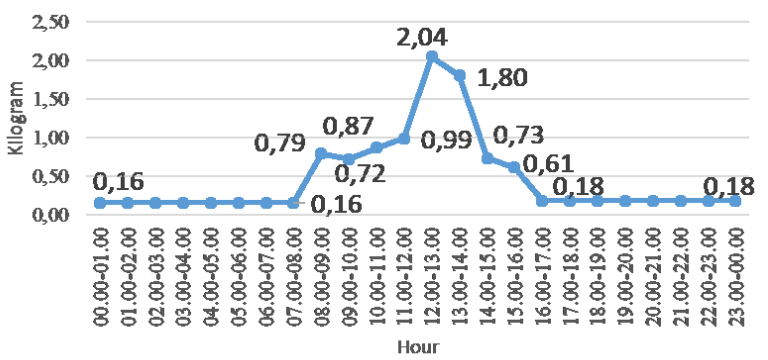

Fig. 9. Fluctuation of the Jangga River

It was found that the generation of waste in the river was dominated by organic waste in the form of leaves and branches at $6.85 \mathrm{~kg} /$ day $(88.33 \% \mathrm{WW})$. Then followed by metal waste of $0.44 \mathrm{~kg} /$ day $(5.63 \% \mathrm{BW})$ which included iron cans. The other dominant waste is plastic waste of $0.27 \mathrm{~kg} /$ day $(3.54 \% \mathrm{WW})$ which includes LDPE and non-aluminum packaging.

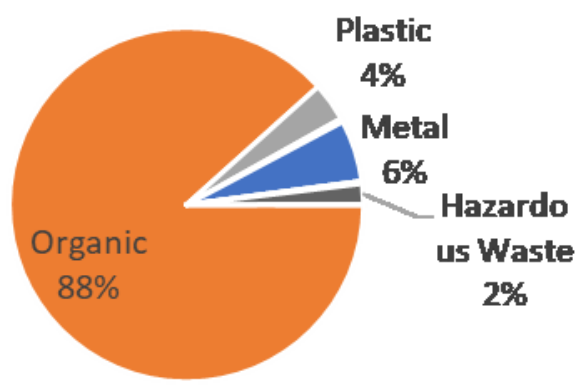

Fig. 10. Waste Composition of the Jangga River

\subsection{Jinah River (Klungkung Regency)}

The Jinah River is a river that empties into the Lepang Beach. And the location of the chosen sampling point is $2.5 \mathrm{~km}$ from the estuary with a width of 18 meters. The Jinah River has $152.02 \mathrm{~km}$ long. Land around the river is still empty land, but at a distance of \pm 70 meters from the river there is a settlement. In the first week of July, the Jinah River was relatively receding with a current speed of $0.227 \mathrm{~m} / \mathrm{s}$ with a water level of $20-60 \mathrm{~cm}$ with a depth of $60 \mathrm{~cm}$ located right in the middle of the river.

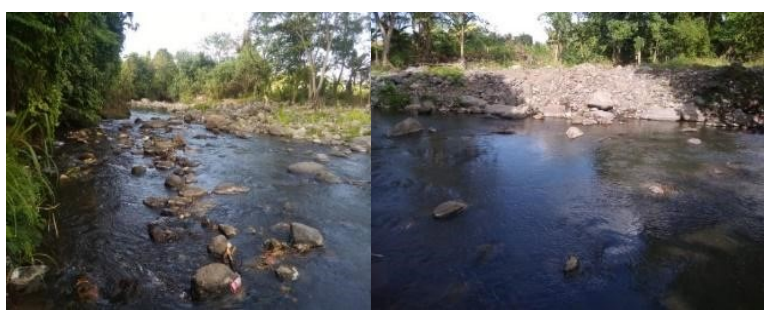

Fig. 11. The Condition of the Jinah River

Obtained the average amount of waste retained in the net is $0.09 \mathrm{~kg} /$ hour or equivalent to $0.005 \mathrm{~kg} / \mathrm{m} /$ hour if divided by the width of the river by the fluctuation of waste listed in Figure 12. The largest waste generation is obtained at $14.00-15.00$ WITA, reaching $0.45 \mathrm{~kg}$ and the lowest waste generation reaching $0.04 \mathrm{~kg}$ with a density of 0.008 tons $/ \mathrm{m}^{3}$.

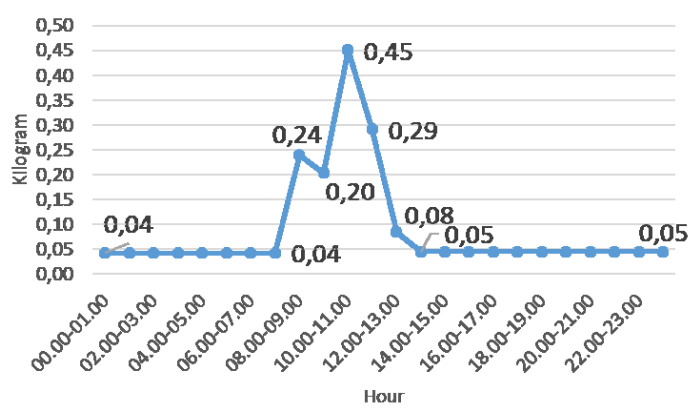

Fig. 12. Jinah River of Waste Fluctuations

It is found that the generation of waste in the river is dominated by organic waste in the form of leaves and twigs of $1.83 \mathrm{~kg} /$ day $(54.79 \% \mathrm{BW})$ followed by plastic waste of $0.74 \mathrm{~kg} /$ day $(22,14 \%$ of BB) including LDPE and non-aluminum packaging. Then there is fabric waste of $0.36 \mathrm{~kg} /$ day $(10.88 \% \mathrm{WW})$. The other dominant waste is paper waste which includes $0.25 \mathrm{~kg} /$ day tetrapack packaging $(7.54 \% \mathrm{WW})$.

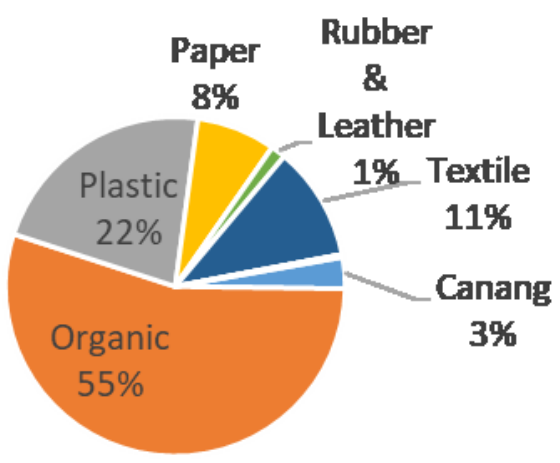

Fig. 13. Waste Composition of Jinah River

\subsection{Loloan River (Denpasar City)}

The Loloan River Trashrack is located in Sanur Kauh Village, South Denpasar District as shown in Figure 14. 


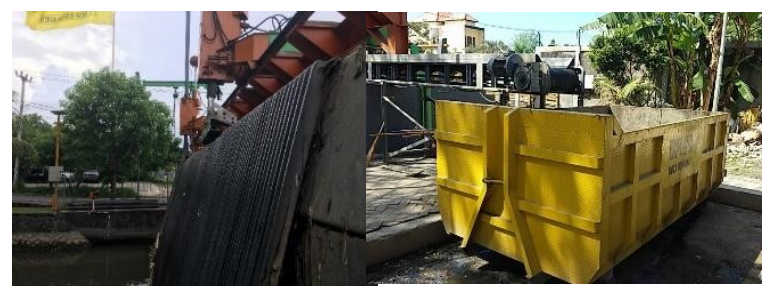

Fig. 14. Loloan Trashrack Condition

Location of the Loloan River Trashrack is precisely at $08^{\circ} 42^{\prime} 21.9564$ "N - $115^{\circ} 14^{\prime} 43.368^{\prime \prime} \mathrm{E}$. The land around the trashrack is a national road and restaurants and shops. The location of the trashrack itself is $\pm 1.1 \mathrm{~km}$ from the estuary located on Mertasari Beach. Obtained an average of waste retained in the net amounted to $64.68 \mathrm{~kg} /$ hour or equivalent to $4.56 \mathrm{~kg} / \mathrm{m} /$ hour if divided by the width of the river, with the fluctuation of waste shown in Figure 15. The biggest waste generation is obtained at $11.00-12.00$ WITA which is $394.79 \mathrm{~kg}$ and the lowest waste generation is $23.11 \mathrm{~kg}$ with a density of 0.261 tons $/ \mathrm{m}^{3}$.

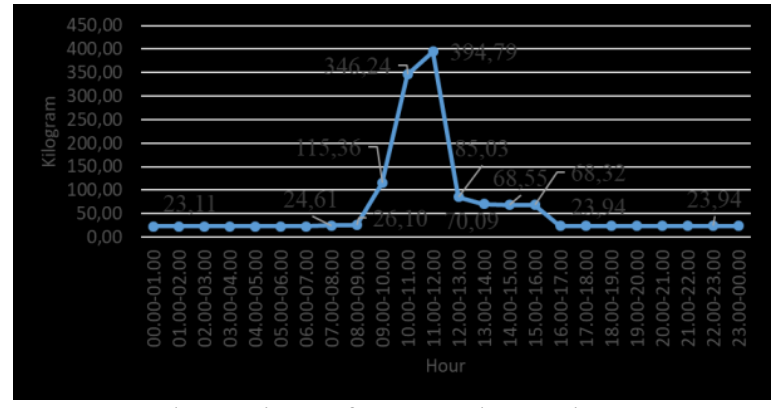

Fig. 15. Loloan River of Waste Fluctuation

Results of the measurement of waste composition states that what dominates waste in the Loloan River is plastic waste of $46.08 \% \mathrm{WW}(2.51 \mathrm{~kg})$ which includes LDPE plastic as shown in Figure 16, followed by organic waste which contributed $30.19 \%$ WW (1.64 kg).

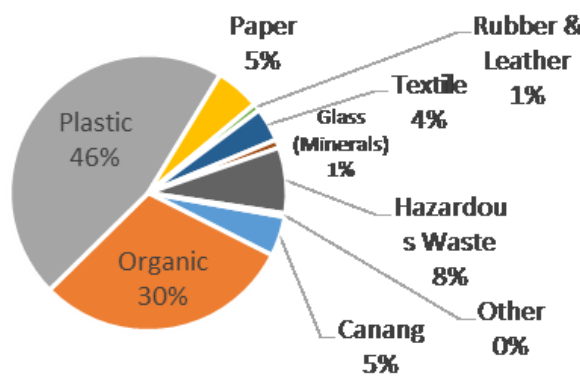

Fig. 16. Loloan River Waste Composition

\subsection{Waste Generation and Composition of River}

It is found that the highest fluctuation of waste generation in the river without trashrack is $1.42 \mathrm{~kg}$ / hour which is at 13.00 - 14.00 WITA with an average generation reaching $035 \mathrm{~kg} /$ hour as shown in Figure 17.

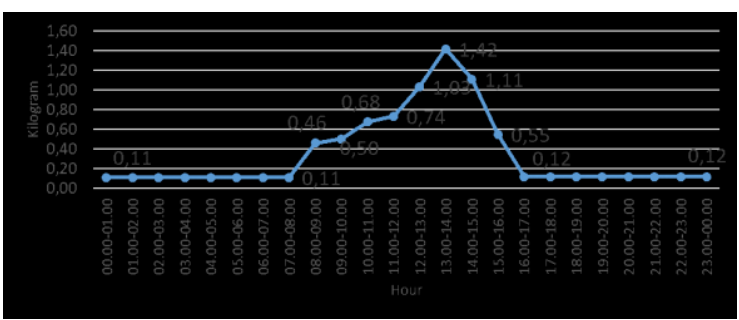

Fig. 17. River Waste fluctuation without trashrack

While the highest fluctuation of river with and without the trashrack reaches $99.25 \mathrm{~kg} /$ hour at $11.00-12.00$ WITA with the average generation reaching $16.43 \mathrm{~kg} /$ hour as shown in Figure 18.

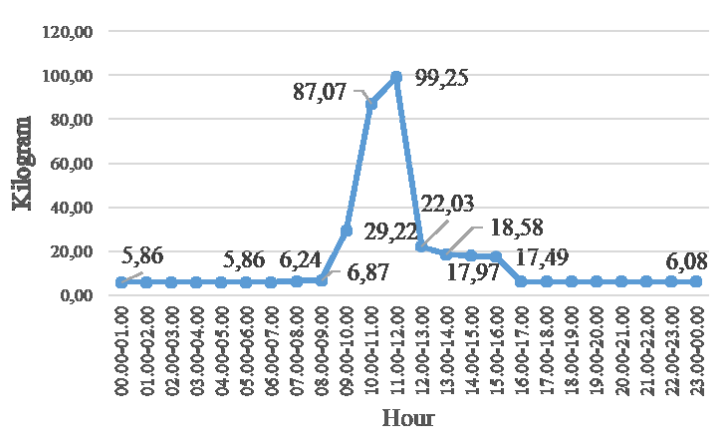

Fig. 18. River waste fluctuations with and without trashrack

It is known that all samples river are surrounded mostly by houses of local community, but there are other possibility sources of waste. Two of possibility waste source are traditional market and tourism activity on beach that can throw waste into the river.

From 4 (four) composition measurement locations, an average composition can be obtained that can represent all waste generation in Bali Province. It was found that the waste that dominated the waste generation in the river was dominated by $59.10 \%$ WW $(3.98 \mathrm{~kg})$ of organic waste including leaves and twigs. Then $17.12 \%$ WW $(1.15 \mathrm{~kg})$ others are hazardous waste which includes baby diapers, medical waste, and electronic equipment waste. In addition, there was also $14.71 \%$ WW $(0.99 \mathrm{~kg})$ of plastic waste which included LDPE plastic as listed in Figure 19.

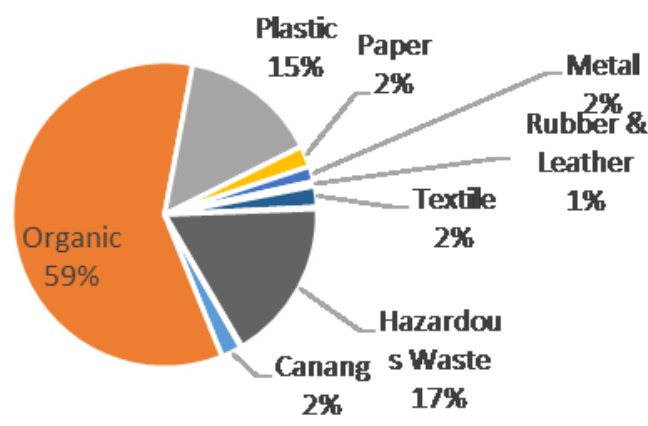

Fig. 19. Average Waste Composition 


\subsection{Yeh Gangga Beach (Tabanan Regency)}

Yeh Gangga Beach is located in Yeh Gangga Village, Tabanan District, Tabanan Regency. Yeh Gangga Beach is a recreational beach which is also often used as a religious ceremony.
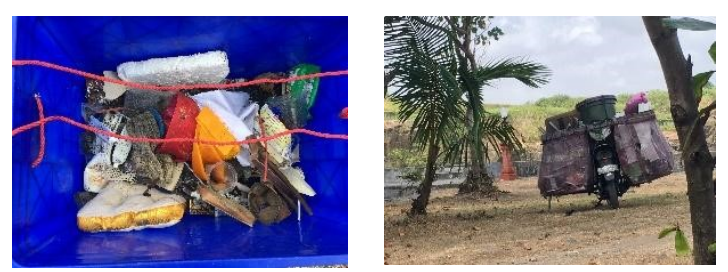

Fig. 20. Conditions of Yeh Gangga Beach

An average of 231 items was found with a weight of $2.07 \mathrm{~kg}$ at $360 \mathrm{~m}^{2}$. Then the amount of landfill waste on the beach to be $0.006 \mathrm{~kg} / \mathrm{m}^{2}$ or 0.64 item $/ \mathrm{m}^{2}$ with a density of 0.088 tons $/ \mathrm{m}^{3}$.

Provided that waste generation in Yeh Gangga Beach is dominated by plastic waste such as in the form of LDPE and PET 0,48 items $/ \mathrm{m}^{2}$ or $0,002 \mathrm{~kg} / \mathrm{m}^{2}(37.67 \% \mathrm{WW})$ followed by rubber and leather waste at 0,01 items $/ \mathrm{m}^{2}$, equivalent to $0.001 \mathrm{~kg} / \mathrm{m}^{2}(24.20 \% \mathrm{WW})$ as shown in Figure 21.

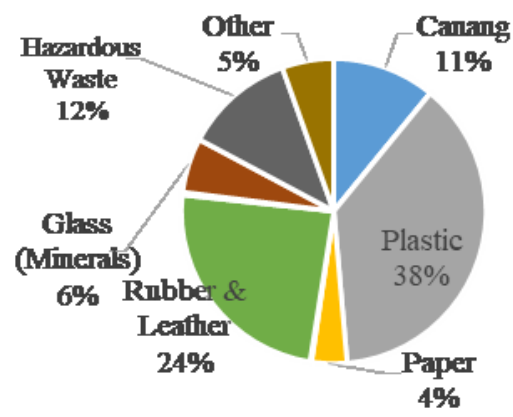

Fig. 21. Waste Composition of Yeh Gangga Beach

\subsection{Jasri Beach (Karangasem Regency)}

Jasri Beach is located in Subangan Village, Karangasem District, Karangasem Regency. Jasri Beach is a beach that functions as a fisherman anchored and religious ceremonies.
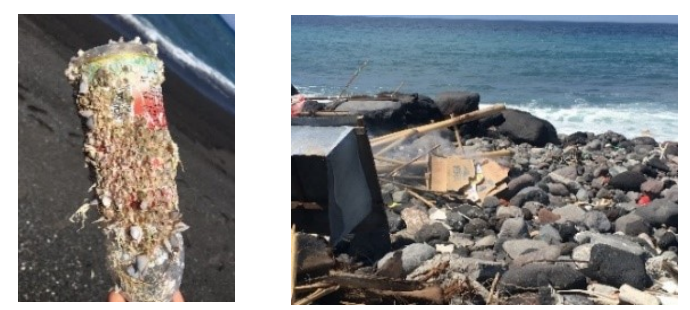

Fig. 22. Jasri Beach Conditions

An average of 223 items with a weight of $1.81 \mathrm{~kg}$ at 360 $\mathrm{m}^{2}$ was found. Then the amount of beach waste to be $0,005 \mathrm{~kg} / \mathrm{m}^{2}$, or 0.62 item $/ \mathrm{m}^{2}$ with a density of 0.091 tons $/ \mathrm{m}^{3}$.

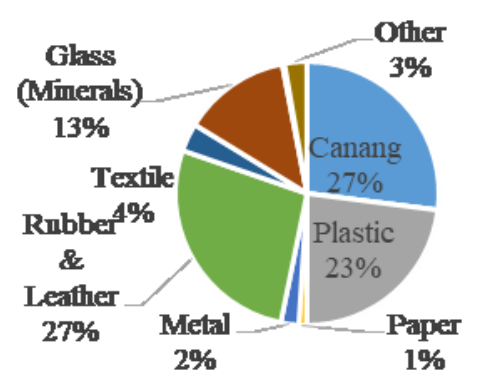

Fig. 23. Waste Composition of Jasri Beach

Provided that waste generation which is at the Jasri Beach dominated by rubber and leather waste such as sandals and pieces of rubber in the form of 0.03 item / $\mathrm{m}^{2}$ or $0,001 \mathrm{~kg} / \mathrm{m}^{2}(27.07 \% \mathrm{WW})$ followed by a religious ceremony waste by 0.23 items $/ \mathrm{m}^{2}$, equivalent to $0.001 \mathrm{~kg} / \mathrm{m}^{2}$. Then there is a form of plastic waste including PVC and LDPE by 0.27 items $/ \mathrm{m}^{2}$, equivalent to $0.001 \mathrm{~kg} / \mathrm{m}^{2}(23.03 \% \mathrm{WW})$ as shown in Figure 23 .

\subsection{Lepang Beach (Klungkung Regency)}

Lepang Beach is located in Lepang Hamlet, Takmung Village, Banjarangkan District, Klungkung Regency. Lepang Beach functions as a recreational facility.
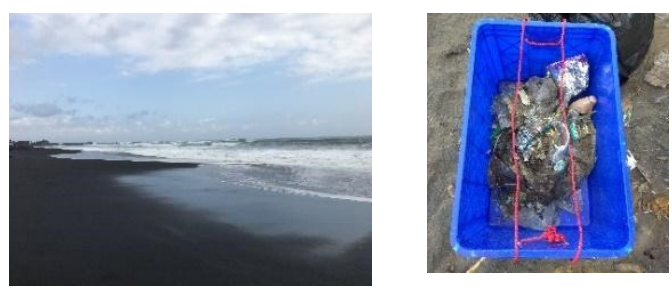

Fig. 24. The Condition of Lepang Beach

It is found an average of 96.17 items with a weight of $2.88 \mathrm{~kg}$ at $360 \mathrm{~m}^{2}$. Then the amount of beach waste was increased to $0.008 \mathrm{~kg} / \mathrm{m}^{2}$ or 0.27 item $/ \mathrm{m}^{2}$ with a density of 0.073 tons $/ \mathrm{m}^{3}$.

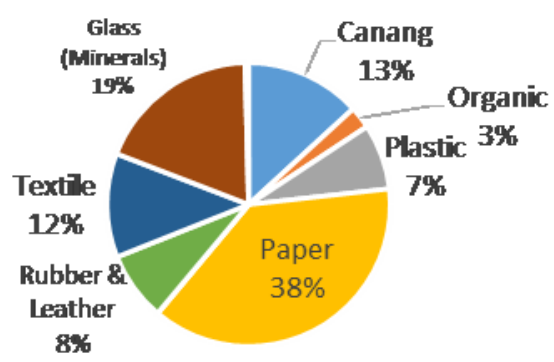

Fig. 25. Waste Composition of Lepang Beach

Provided that the waste is in Lepang Beach dominated by paper waste that amounted to 0.02 items $/ \mathrm{m}^{2}$ or 0.003 $\mathrm{kg} / \mathrm{m}^{2}(37.86 \% \mathrm{WW})$ followed by glass waste that include a snippet glass and glass of 0.003 items $/ \mathrm{m}^{2}$, equivalent to $0.002 \mathrm{~kg} / \mathrm{m}^{2}$. Then there are canang waste by 0.07 items $/ \mathrm{m}^{2}$, equivalent to $0.001 \mathrm{~kg} / \mathrm{m}^{2}(13.21 \%$ WW) as shown in Figure 25. 


\subsection{Mertasari Beach (Denpasar City)}

Mertasari Beach is located in Sanur Kauh Village, South Denpasar District, Denpasar City. Mertasari Beach serves as a recreational facility and there are 2 rivers that run on the beach, the Rangda River and the Loloan River.

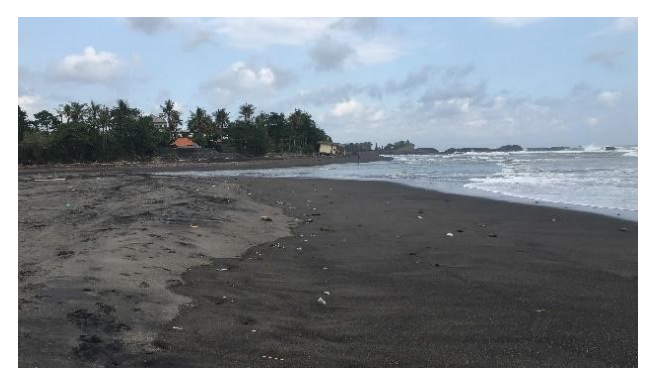

Fig. 26. Mertasari Beach Conditions

An average of 218 items was found with a weight of $3.37 \mathrm{~kg}$ at $360 \mathrm{~m}^{2}$. Then the amount of beach waste to be $0.009 \mathrm{~kg} / \mathrm{m}^{2}$ or 0.61 item $/ \mathrm{m}^{2}$ with a density of 0.097 tons $/ \mathrm{m}^{3}$.

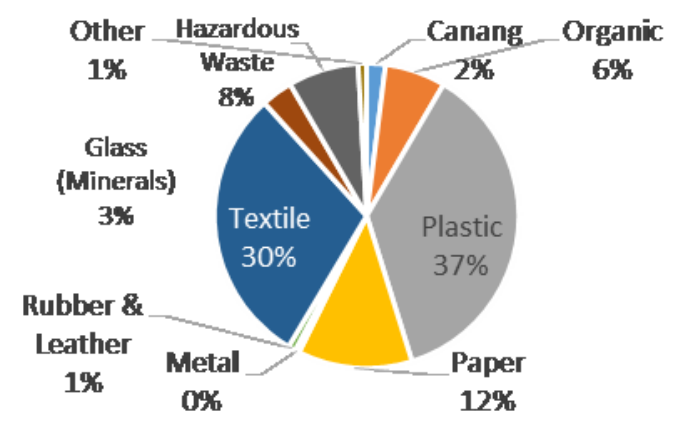

Fig. 27. Waste Composition Mertasari Beach

Provided that waste generation in Mertasari Beach which is dominated by plastic waste include packaging plastic and aluminum 0,46 items $/ \mathrm{m}^{2}$ or $0,003 \mathrm{~kg} / \mathrm{m}^{2}(36.73 \%$ WW) followed by textiles waste such as cloth and rags of 0,031 items / $\mathrm{m}^{2}$, equivalent to $0.003 \mathrm{~kg} / \mathrm{m}^{2}(29.67 \%$ WW) as shown in Figure 27.

\subsection{Waste Generation and Composition of Beach}

Occurrence an average of 192.33 items was found with a weight of $2.53 \mathrm{~kg}$ at $360 \mathrm{~m}^{2}$. Then the amount of landfill waste on the beach to be $0,007 \mathrm{~kg} / \mathrm{m}^{2}$ or 0.53 item $/ \mathrm{m}^{2}$ with a density of 0.087 tons $/ \mathrm{m}^{3}$.

Provided that the average waste generation is dominated by plastic waste which include LDPE 0.33 item $/ \mathrm{m}^{2}$ or $0.002 \mathrm{~kg} / \mathrm{m}^{2}(26.18 \% \mathrm{WW})$ followed by paper waste by 0,021 items $/ \mathrm{m}^{2}$, equivalent to $0.001 \mathrm{~kg} / \mathrm{m}^{2}(15.73 \%$ WW) and waste including textiles such as cloth and rags of 0.02 item $/ \mathrm{m}^{2}$ or $0.001 \mathrm{~kg} / \mathrm{m}^{2}(13.91 \% \mathrm{WW})$ as shown in Figure 28.

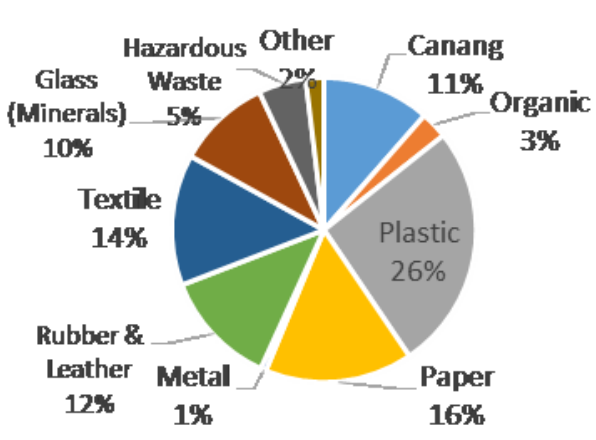

Fig. 28. Average Coastal Waste Composition

\section{Conclusion}

From the results of the measurement of river waste, it was found that the pattern of community waste disposal is likely to occur in the morning or evening so that it arrives at the sampling point location which is downstream of the river at $11.00-12.00$ WITA and $13.00-14.00$ WITA. The average obtained reaching river waste generation is $0.35 \mathrm{~kg}$ / hour in rivers without trashrack, and $16.43 \mathrm{~kg}$ / hour in rivers with and without trashrack. Then the dominant waste is organic, hazardous waste and plastic waste so that it can be stated that waste originating from rivers has the potential to be biologically treated and followed by recycling treatment for plastic waste, reinforced by the presence of paper and textile waste which is also recyclable waste, and hazardous waste handling. While the type of plastic waste that dominates is LDPE plastic which states that people who use disposable plastic bags are still relatively high.

Then from the measurement of beach waste, obtained a small waste density, which is equal to 0.087 tons $/ \mathrm{m}^{3}$, indicating that the waste that dominates is light waste. Strengthened by measuring the composition of waste which states that beach waste is dominated by plastic waste, paper waste, and textile waste. And the amount of beach waste average reached $0.007 \mathrm{~kg} / \mathrm{m}^{2}$ or 0.53 item / $\mathrm{m}^{2}$, with Yeh Gangga Beach is the dirtiest waste to pile items $0.64 / \mathrm{m}^{2}$ and a Lepang Waste is the cleanest beach with a pile 0.27 items $/ \mathrm{m}^{2}$.

\section{Acknowledgement}

This research was funded from the Research Program, Community Service and Innovation (P3MI) ITB Expertise Group in 2019.

\section{References}

1. Intergovernmental Panel on Climate Change, Managing the Risks of Extreme Events and Disaster to Advance Climate Change Adaptation. IPCC (2012).

2. United Nation Environment Program, Marine Litter-Trash That Kills. Brochure (2001). 
3. T.R. Lookingbill, S.S. Kaushal, A.J. Elmore, R. Gardner, K.N. Eshleman, R.H. Hilderbrand, R.P. Morgan, W.R. Boynton, M.A. Palmer, W.C. Dennison. Ecol. Soc. 14 (2), 10 (2009).

4. A.L. Andrady. Mar. Pollut. Bull 62, 1596-1605. (2011)

5. D.K. Barnes, F. Galgani, R.C. Thompson, M. Barlaz. Philos. Trans. R. Soc. Lond. Ser. B Biol. Sci 364, 1985-1998. (2009)

6. Greenpeace. Plastic Debris in the World's Oceans (2006)

7. Barretto, F, Scientists set sail for first global study of "Plastic Soup" at Sea. Accessed April 7, 2019 from Global Waste (2010)

8. Republika. May 6, Clearing Trash, Bali Spent Rp. 500 Million. Accessed April 7, 2019 from Republika (2011).

9. Davenport, John and Davenport, Julia L. Estuarine, Coastal and Shelf Science, 67, 280-292. (2006)

10. Bali Provincial Statistics, 2017

11. Beccarello, Massimo, Giacomo Di Foggia. Waste Management, 79, 223 -231 (2018)

12. Burnley, Stephen, Terry Coleman. Waste Management, 79, 79-86 (2018)

13. Yamane, Taro, Statistics, An Introductory Analysis, 2nd Ed., New York: Harper and Row (1967) 